CASSOWARY volume 2 (1): 86 - 101

ISSN : 2614-8900

E-ISSN : 2622-6545

CProgram Pascasarjana Universitas Papua, https://pasca.unipa.ac.id/

\title{
Studi adsorpsi limbah organik industri tahu tempe dengan karbon aktif kayu merbau [Intsia bijuga (Colebr) O. Kuntze]
}

\author{
Study of adsorption of organic waste from tofu and tempe with activated carbon of \\ merbau wood [Intsia bijuga (Colebr) O. Kuntze]
}

\section{Noor Endah Setyaningrum, Bimo Budi Santoso dan Bertha Mangallo}

\author{
Program Magister Ilmu Lingkungan, Program Pascasarjana Universitas Papua, \\ Manokwari 98314, Indonesia. \\ E-mail : noorendahsns@gmail.com
}

\begin{abstract}
Study on adsorption of tofu and tempe industrial organic waste with timber wood [Intsia bijuga (Colebr) O. Kuntze] as the active carbon has been executed. The objective the research is to determine the optimum required consentration of $\mathrm{HCl}$ to active the coal of timber wood, discover optimum adsorption capacity of timber charcoal to reduce the level of $\mathrm{BOD}_{5}$ dan $\mathrm{COD}$ in fluids waste of tofu and tempe industry. Research method of activating timber wood charcoal is physically by heating $700^{\circ} \mathrm{C}$ of temperature and chemically by submersion in $\mathrm{HCl} 1 \mathrm{M}, 2 \mathrm{M}$ and $3 \mathrm{M}$. First, variation is made of contact duration of timber wood active carbon and fluid waste for 30, 60, 90 and 120 minutes. Then, volume of fluid waste is also differed by 100, 150, 200,250 and $300 \mathrm{ml}$ per 0.5 gram of active carbon. Result of the research shows that optimum condition for adsorption of tofu and tempe industrial fluid waste are as follow : at consentrate of $\mathrm{HCl} \mathrm{3M}$, contact duration 30 minutes, fluid waste volume $250 \mathrm{ml}$ per 0.5 gram of active carbon, optimum adsorption capacity of timber wood active carbon is achieved which lowering the level of $\mathrm{BOD}_{5}$ and COD of Rizky tofu and tempe industrial fluid waste; each by $60,600 \mathrm{mg} / \mathrm{g}$ and $12,500 \mathrm{mg} / \mathrm{g}$. On the state where volume of the waste is $100 \mathrm{ml}$ per 0.5 gram, optimum adsorption capacity of the timber wood active carbon in reducing the $\mathrm{BOD}_{5}$ and COD level of Sukamaju tofu and tempe industrial fluid waste is $82,400 \mathrm{mg} / \mathrm{g}$ and $164,200 \mathrm{mg} / \mathrm{g}$ each.
\end{abstract}

Keyword : Adsorption, BOD, , COD, tofu and tempe industrial fluid waste, active carbon, wood.

ABSTRAK: Studi tentang adsorpsi limbah organik industri tahu dan tempe dengan kayu kayu [Intsia bijuga (Colebr) O. Kuntze] ketika karbon aktif telah dieksekusi. Tujuan dari penelitian ini adalah untuk menentukan konsentrasi $\mathrm{HCl}$ yang diperlukan untuk mengaktifkan batubara kayu kayu, menemukan kapasitas adsorpsi arang kayu yang optimal untuk mengurangi tingkat BOD5 dan COD dalam limbah cair industri tahu dan tempe. Metode penelitian untuk mengaktifkan arang kayu kayu secara fisik dengan memanaskan suhu $700 \mathrm{oC}$ dan secara kimiawi dengan perendaman dalam $\mathrm{HCl}$ $1 \mathrm{M}, 2 \mathrm{M}$ dan 3M. Pertama, variasi dibuat dari durasi kontak karbon aktif kayu dan limbah cair selama 30, 60, 90 dan 120 menit. Kemudian, volume limbah cair juga berbeda dengan $100,150,200,250$ dan $300 \mathrm{ml}$ per 0,5 gram karbon aktif. Hasil 
penelitian menunjukkan bahwa kondisi optimum untuk adsorpsi limbah cair industri tahu dan tempe adalah sebagai berikut: pada konsentrasi $\mathrm{HCl} 3 \mathrm{M}$, durasi kontak 30 menit, volume limbah cair $250 \mathrm{ml}$ per 0,5 gram karbon aktif, kapasitas adsorpsi optimal kayu kayu Karbon aktif dicapai yang menurunkan tingkat BOD5 dan COD dari tahu Rizky dan limbah cair industri tempe; masing-masing sebesar $60.600 \mathrm{mg} / \mathrm{g}$ dan 12.500 $\mathrm{mg} / \mathrm{g}$. Pada keadaan di mana volume limbah adalah $100 \mathrm{ml}$ per 0,5 gram, kapasitas adsorpsi optimal dari karbon aktif kayu kayu dalam mengurangi BOD5 dan tingkat COD dari tahu Sukamaju dan limbah cair industri tempe masing-masing adalah 82.400 $\mathrm{mg} / \mathrm{g}$ dan $164.200 \mathrm{mg} / \mathrm{g}$.

Kata kunci: Adsorpsi, $\mathrm{BOD}_{5}, \mathrm{COD}$, industri tahu dan tempe, limbah cair, karbon aktif, kayu.

\section{PENDAHULUAN}

Tahu dan tempe merupakan salah satu jenis makanan sumber protein dengan bahan baku kacang kedelai yang sangat digemari oleh masyarakat karena sehat, bergizi dan harganya murah. Kota Manokwari memiliki 10 industri tahu dan tempe, yaitu Banyumas, Sukamaju, Sumber Gizi, Rizky, Cipta Rasa, Pasar Wosi, Mandiri, Cahaya Transito, Margiono dan Fanindi (BLH Kabupaten Manokwari, 2015). Semua industri tahu tempe tersebut merupakan industri kecil skala rumah tangga yang tidak dilengkapi dengan unit pengolah air limbah. Selain itu, semua industri tahu tempe ini berlokasi di daerah pinggiran sungai dan tepi laut serta tidak memiliki ruang yang cukup untuk membuat system pengelolaan limbah cairnya sehingga semua industri tersebut mengalirkan limbahnya ke badan air.

Pada tahun 2013 terdapat pengaduan masyarakat yang mengeluhkan gangguan bau yang dihasilkan oleh industri tahu tempe Sukamaju yang berlokasi di Kampung Jawa Wosi Manokwari (BLH Kabupaten Manokwari, 2013). Daerah Kampung Jawa Wosi Manokwari merupakan salah satu daerah padat penduduk dan terdapat 3 industri tahu tempe, yaitu industri tahu tempe Banyumas, Sumber Gizi dan
Sukamaju. Industri tahu tempe Sukamaju menggunakan bahan baku sebanyak $200 \mathrm{~kg}$ kedelai per hari untuk membuat tahu tempe dengan pembagian bahan baku $50 \mathrm{~kg}$ kedelai untuk pembuatan tempe dan $150 \mathrm{~kg}$ kedelai untuk pembuatan tahu kemudian hasil uji air limbahnya menunjukkan konsentrasi COD sebesar $517 \mathrm{mg} / \mathrm{L}$. Selain itu, industri tahu tempe Rizky menggunakan bahan baku kedelai sebanyak 400 $\mathrm{kg}$ per hari dengan pembagian bahan baku $100 \mathrm{~kg}$ kedelai untuk membuat tempe dan $300 \mathrm{~kg}$ kedelai untuk membuat tahu. Hasil uji air limbah industri tahu tempe Rizky menunjukkan konsentrasi COD sebesar $1122 \mathrm{mg} / \mathrm{L}$ (BLH Kabupaten Manokwari, 2013). Banyaknya bahan baku kedelai yang digunakan oleh industri tahu tempe Rizky menyebabkan kandungan konsentrasi COD dalam air limbah industri ini meningkat. Peraturan Menteri Lingkungan Hidup No. 15 Tahun 2008 menyebutkan baku mutu konsentrasi COD adalah $300 \mathrm{mg} / \mathrm{L}$, sehingga air limbah industri tahu tempe Sukamaju dan Rizky melebihi baku mutu yang telah ditetapkan oleh Pemerintah dan harus diolah sebelum dibuang ke badan air atau lingkungan.

Salah satu teknik pengolahan air limbah industri tahu tempe adalah dengan penggunaan karbon aktif. Karbon 
aktif merupakan arang yang sudah diaktifkan sehingga pori-porinya terbuka dengan demikian daya adsorpsinya tinggi. Pada pembuatan karbon aktif, untuk meningktakan daya adsorpsinya dilakukan dengan dua proses, yaitu aktivasi fisik dan aktivasi kimia. Karbon aktif yang digunakan berasal dari kayu merbau (kayu besi) dari limbah mebel yang diaktivasi secara kimia dengan menggunakan larutan $\mathrm{HCl}$

Penelitian ini bertujuan untuk 1) Menentukan konsentrasi optimum $\mathrm{HCl}$ yang digunakan untuk mengaktivasi arang kayu merbau dalam menurunkan kadar $\mathrm{BOD}_{5}$ dan $\mathrm{COD}$ limbah organik industri tahu tempe, 2) Menentukan waktu kontak optimum karbon aktif kayu merbau dalam menurunkan kadar $\mathrm{BOD}_{5}$ dan COD limbah organik industri tahu tempe, 3) Menentukan kapasitas adsorpsi optimum karbon aktif kayu merbau dalam menurunkan kadar BOD dan COD limbah organik industri tahu tempe.

\section{METODE PENELITIAN}

Penelitian dilakukan selama 6 bulan dari bulan Februari 2017 sampai dengan Agustus 2017. Lokasi pengambilan sampel kayu merbau berasal dari limbah kayu industri mebel Sinar Sowi yang beralamat di jalan poros Sowi 4 Manokwari. Sampel limbah cair industri tahu tempe yang merupakan limbah organik diambil pada lokasi outlet (bak penampungan) industri tahu tempe Sukamaju dan industry tahu tempe Rizky di Kabupaten Manokwari

Variabel yang diamati adalah kandungan karakteristik limbah cair industri tahu tempe industri Sukamaju dan Rizky, yaitu Biological Oxygen Demand (BOD5) dan Chemical Oxygen Demand (COD). Variabel operasional pada penelitian ini adalah konsentrasi aktivator $\mathrm{HCl}$, waktu kontak, daya serap/ kapasitas adsorpsi karbon aktif kayu merbau dan volume limbah cair industri tahu tempe.

Metode penelitian yang digunakan adalah metode eksperimen di laboratorium, pengambilan sampel menggunakan teknik purposive sampling dan Metode pengambilan sampel yang digunakan adalah metode grab sampling, yaitu pengambilan sampel hanya dilakukan satu kali serta Teknik pengambilan sampel limbah cair menggunakan metode SNI 6989.59 2008 tentang metode pengambilan contoh air limbah.

\section{PROSEDUR PENELITIAN}

\section{Pembuatan Karbon Aktif Kayu Merbau}

a. Pembuatan Arang

kayu merbau dikeringkan di bawah sinar matahari selama kurang lebih 1 hari, setelah itu dimasukkan dalam kaleng yang sebelumnya pada bagian bawah kaleng dimasukkan sehelai kertas dan sabut kelapa, kemudian dibubuhi minyak tanah dan dibakar. Proses pembakaran (karbonisasi) dilakukan dengan teknik kiln drum, yaitu pembakaran dengan udara terbatas selama $\pm 6-7$ jam.

\section{b. Proses Penggilingan}

Arang kayu merbau yang diperoleh digiling menggunakan crusher, setelah itu diayak menggunakan ayakan $-100+150$ mesh (lolos 100 mesh, tertahan 150 mesh).

\section{c. Aktivasi Karbon}

Serbuk arang yang diperoleh dibagi 2 (dua) bagian, satu bagian tanpa aktivator (blanko) atau aktivasi fisik dengan suhu $700^{\circ} \mathrm{C}$ selama 3 jam dan satu bagian lainnya dibagi lagi menjadi 
tiga bagian. Kemudian masing-masing bagian ini dicampur dengan larutan $\mathrm{HCl}$ $1 \mathrm{M}, 2 \mathrm{M}$ dan $3 \mathrm{M}$ dengan perbandingan 1 : 10 (10 g arang dengan $100 \mathrm{ml}$ larutan) dan dididihkan selama 1,5 jam. Selanjutnya arang tersebut didinginkan kemudian disaring dan dicuci hingga netral. Setelah itu, sampel dipindahkan ke dalam cawan yang memakai penutup dan dimasukkan dalam tanur listrik dan diaktivasi pada suhu $600^{\circ} \mathrm{C}$ selama 3 jam. Kemudian dicuci dengan air mendidih pada suhu $100^{\circ} \mathrm{C}$ selama 3 menit dan dikeringkan dalam oven pada suhu $110^{\circ} \mathrm{C}$ selama 2 jam (Manarisip, 1984 dalam Endah, 2005).

\section{Pengujian Karakteristik Karbon Aktif Kayu Merbau}

\section{a. Penetapan Kadar Air}

Prosedur penetapan kadar air mengacu pada SNI 06 - 3730 - 1995 tentang syarat mutu dan pengujian karbon aktif. Contoh uji (karbon aktif) sebanyak $1 \mathrm{~g}$ dimasukkan ke dalam cawan porselin yang memiliki bobot konstan, selanjutnya dikeringkan dalam oven pada suhu $(103 \pm 2)^{\circ} \mathrm{C}$. Kemudian dimasukkan ke dalam desikator selanjutnya ditimbang sampai bobotnya tetap dan ditentukan kadar airnya dalam persen $(\%)$.

Rumus perhitungan kadar air :

$\operatorname{kadar} \operatorname{air}(\%)=\frac{a-b}{a} \times 100 \%$

Keterangan: $\mathrm{a}=$ massa awal karbon aktif kayu merbau sebelum di oven (g), $\mathrm{b}=$ massa akhir karbon aktif kayu merbau setelah di oven $(\mathrm{g})$

\section{b. Penetapan Kadar Abu}

Prosedur penetapan kadar abu mengacu pada SNI 06 - 3730 - 1995 tentang syarat mutu dan pengujian karbon aktif. Cawan yang telah berisi $1 \mathrm{~g}$ karbon aktif pada uji penetapan kadar air, digunakan untuk mengukur kadar abu dengan cara memasukkan cawan porselen ini dalam tanur listrik dengan suhu $600^{\circ} \mathrm{C}$ selama 6 jam. Selanjutnya didinginkan dalam desikator dan ditimbang hingga bobotnya konstan.

Rumus perhitungan kadar abu :

$$
\text { Kadar abu }(\%)=\frac{b}{a} \times 100 \%
$$

Keterangan: $\mathrm{a}=$ massa awal karbon aktif sebelum di tanur ( $\mathrm{g}), \mathrm{b}=$ massa akhir karbon aktif setelah di tanur (g).

\section{c. Daya Serap terhadap $I_{2}$}

Prosedur penetapan daya serap terhadap $\mathrm{I}_{2}$ mengacu pada SNI 06 - 3730 - 1995 tentang syarat mutu dan pengujian karbon aktif. Sampel karbon aktif yang telah kering oven ditimbang sebanyak $\pm 0.25 \mathrm{~g}$ dan dimasukkan kedalam labu Erlenmeyer. Kemudian sampel tersebut diberi $25 \mathrm{~mL}$ larutan iodium $0.1 \mathrm{~N}$, selanjutnya diaduk dengan menggunakan stirrer selama \pm 15 menit. Larutan yang telah diaduk kemudian disaring dengan menggunakan kertas saring dan hasilnya dipipet $10 \mathrm{~mL}$ untuk titrasi menggunakan larutan thiosulfat $0.1 \mathrm{~N}$. Selanjutnya ditambahkan 1 tetes amilum $1 \%$ kemudian dititrasi. Titrasi dilakukan hingga larutan sampel berubah warna menjadi bening.

Rumus perhitungan daya serap terhadap $I_{2}$ :

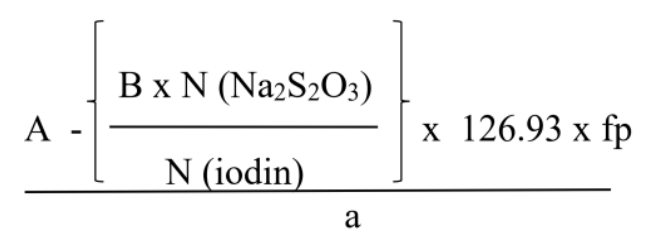


Keterangan: $\mathrm{A}=$ volume larutan iodine $(\mathrm{mL}), \mathrm{B}=$ volume natrium tiosulfat $/$ $\mathrm{Na}_{2} \mathrm{~S}_{2} \mathrm{O}_{3}(\mathrm{~mL}), \mathrm{fp}=$ faktor pengenceran, $\mathrm{a}=$ massa karbon aktif $(\mathrm{g}), \mathrm{N}$ $\left(\mathrm{Na}_{2} \mathrm{~S}_{2} \mathrm{O}_{3}\right)=$ konsentrasi natrium tiosulfat $(\mathrm{N}), \mathrm{N}$ (iodin) = konsentrasi iodin $(\mathrm{N}), 126.93=$ jumlah iodin sesuai $1 \mathrm{~mL}$ larutan $\mathrm{Na}_{2} \mathrm{~S}_{2} \mathrm{O}_{3}$

Pengujian Karakteristik Limbah Cair Industri Tahu Tempe Dan Pengujian Daya Serap/ Kapasitas Adsorpsi Karbon Aktif Kayu Merbau Pada Limbah Cair Industri Tahu Tempe

1). Menurut Irmanto dan Suyata (2009), Uji nilai Bioligical Oxygen Demand (BOD) dalam limbah cair industri tahu tempe (APHA, 1995).

Pengukuran BOD dilakukan menggunakan metode titrasi winkler. Kemudian dapat ditentukan kadar BOD.

\section{Penentuan $\mathrm{DO}_{0}$}

Pipet $10 \mathrm{ml}$ sampel limbah cair industri tahu tempe kedalam labu ukur $100 \mathrm{ml}$, ditambahkan masing-masing 1 $\mathrm{ml}$ buffer fosfat, $\mathrm{MgSO}_{4}, \mathrm{CaCl}_{2}$, dan $\mathrm{FeCl}_{3}$ kemudian encerkan dengan air suling sampai tanda batas. Pindahkan kedalam beker $1000 \mathrm{ml}$ lalu aerasi selama 15 menit. Setelah itu dimasukkan kedalam botol winkler dan tutup. Tambahkan masing-masing $1 \mathrm{ml}$ alkali azida dan $\mathrm{MnSO}_{4} 10 \%$, tutup lalu kocok dengan cara membolak-balikkan botol winkler. Dibiarkan selama 10 menit lalu dipindahkan ke Erlenmeyer. Selanjutnya tambahkan $1 \mathrm{ml} \quad \mathrm{H}_{2} \mathrm{SO}_{4}$ pekat, kocok dan titrasi dengan larutan tiosulfat $0.025 \mathrm{~N}$ hingga kuning pucat (mendekati coklat muda). Kemudian tambahkan beberapa tetes amilum atau kanji $1 \%$ (akan timbul warna biru) kemudian ditirasi sampai warna biru tepat hilang.

Rumus kadar oksigen terlarut (DO) :

$$
=\frac{(\mathrm{VxN}) \operatorname{titran} \times 8 \times 1000}{\text { V sampel }}
$$

Keterangan: $\mathrm{V}$ titran $=$ Volume Tiosulfat/ $\quad \mathrm{Na}_{2} \mathrm{~S}_{2} \mathrm{O}_{3} \quad(\mathrm{~mL})$, $\mathrm{N}$ titran $=$ Normalitas tiosulfat $(\mathrm{N})$, $8=$ Berat ekivalen $(\mathrm{BE}) \mathrm{O}_{2}$, $1000=\mathrm{mL}$ perliter air, $\mathrm{V}$ sampel $=$ Volume air limbah (mL)

\section{Penentuan $\mathrm{DO}_{5}$}

Sampel yang telah diaerasikan pada pengerjaan $\mathrm{DO}_{0}$ dimasukkan kedalam botol winkler dan ditutup rapat (dijaga jangan sampai timbul rongga udara) kemudian disimpan selama 5 hari. Selanjutnya dititrasi dengan cara yang sama dengan penentuan $\mathrm{DO}_{0}$.

Rumus perhitungannya sama dengan perhitungan DOo. Sehingga :

Rumus perhitungan $\mathrm{BOD}=\mathrm{DO}-\mathrm{DO}_{5}$

\section{2). Uji nilai Chemical Oxygen Demand (COD) dalam limbah cair industri tahu dan tempe menggu- nakan metode spektrofotometri}

Pipet $10 \mathrm{ml}$ sampel limbah cair (filtrate) kedalam kuvet. Kemudian ditambahkan reagen COD Hach kedalam kuvet dan dikocok perlahan agar homogen. Selanjutnya didiamkan sebentar, lalu sampel dimasukkan kedalam spektrofotometri untuk dilakukan pembacaan nilai COD. Spektrofotometri yang digunakan adalah Spektrofotometri Hach 3900 dimana pembacaan nilai COD berdasarkan panjang gelombangnya, yaitu $320 \mathrm{~nm}$. 


\section{3). Pengujian/ penentuan konsentrasi optimum aktivator $\mathrm{HCl}$}

Pipet $100 \mathrm{ml}$ sampel limbah cair (outlet) kedalam masing-masing Erlenmeyer $250 \mathrm{ml}$. Kemudian ditambahkan kedalam masing-masing Erlenmeyer tersebut 0.5gram karbon aktif yang diaktivasi fisik dan diaktivasi kimia dengan HCL $1 \mathrm{M}, 2 \mathrm{M}$ dan $3 \mathrm{M}$. Selanjutnya distirer selama 30 menit lalu disaring. Filtrat masing-masing Erlenmeyer dibagi 3 untuk pengujian BODo, $\mathrm{BOD}_{5}$ dan COD. Hal ini dilakukan sebanyak dua kali pengulangan (duplo).

\section{4). Pengujian/ penentuan waktu kontak optimum karbon aktif dengan limbah cair industri tahu tempe}

Pipet $100 \mathrm{ml}$ sampel limbah cair (outlet) kedalam masing-masing Erlenmeyer $250 \mathrm{ml}$. Kemudian ditambahkan kedalam masing-masing Erlenmeyer tersebut 0.5 gram karbon aktif yang menghasilkan daya serap optimum pada langkah diatas. Selanjutnya distirer selama 30 menit, 60 menit, 90 menit, dan 120 menit. Lalu disaring, filtrat pada masing-masing Erlenmeyer dibagi tiga bagian untuk pengujian BODo, $\mathrm{BOD}_{5}$ dan $\mathrm{COD}$. Hal ini dilakukan dua kali pengulangan (duplo).

\section{5). Pengujian/ penentuan kapasitas adsorpsi optimum karbon aktif kayu merbau dengan variasi volume limbah cair industri tahu tempe}

Pipet $100 \mathrm{ml}, 150 \mathrm{ml}, 200 \mathrm{ml}$, $250 \mathrm{ml}$ dan $300 \mathrm{ml}$ sampel limbah cair (outlet) kedalam masing-masing erlenmeyer $500 \mathrm{ml}$. Kemudian kedalam masing-msing Erlenmeyer tersebut ditambahkan karbon aktif pada langkah diatas sebanyak 0.5 gram, lalu distirer selama waktu optimum yang telah dihasilkan pada langkah diatas. Selanjutnya disaring dan filtrate masing-masing Erlenmeyer tersebut dibagi 3 bagian untuk dilakukan pengujian $\mathrm{BODo} \mathrm{BOD}_{5}$ dan COD. Hal ini dilakukan dua kali pengulangan (duplo).

\section{HASIL DAN PEMBAHASAN}

Sampel penelitian berupa karbon aktif kayu merbau dengan berbagai jenis variasi konsentrasi aktivator $\mathrm{HCl}$ dalam Tabel 1 memiliki karakteristik seperti kadar air, kadar abu dan daya serap $\mathrm{I}_{2}$. Pengujian kadar air karbon aktif kayu merbau bertujuan untuk mengetahui sifat higroskopis dari karbon aktif tersebut.

Bertambahnya

mengakibatkan sifat higroskopis karbon aktif menjadi meningkat. Gambar 1 menunjukkan bahwa arang kayu merbau yang diaktivasi secara kimia dengan $\mathrm{HCl} 3 \mathrm{M}$ (sampel IV) nilai kadar airnya lebih kecil dibandingkan dengan sampel III. Hal ini berarti dalam sampel III telah terjadi keseimbangan higroskopis atau keadaan tepat jenuh sehingga nilai kadar airnya dalam kondisi maksimal. Setelah keseimbangan terjadi, penambahan konsentrasi $\mathrm{HCl}$ pada sampel IV menyebabkan turunnya nilai kadar air. Hal ini berarti sifat higroskopis sampel IV juga mengalami penurunan.

Menurut Tsoumis (1991), Sifat higroskopis menyebabkan arang aktif pada kondisi dan kelembaban tertentu akan mencapai keseimbangan kadar air, keseimbangan kadar air ini merupakan ukuran higroskopisitas. Selain itu menurut Hendaway (2003) dalam Emmy Sahara, et al., (2017) kadar air sangat dipengaruhi oleh 
jumlah uap air diudara, lama proses pendinginan dan sifat higroskopis dari arang tersebut. Menurut Prastiwi (2014) kadar air yang terkandung dalam karbon aktif juga dipengaruhi oleh jumlah uap air diudara, lama proses pendinginan, penggilingan dan pengayakan.
Pengujian karakteristik selanjutnya adalah kadar abu. Kadar abu merupakan banyaknya kandungan oksida logam yang terdiri dari mineralmineral dalam suatu bahan yang tidak menguap pada proses pengabuan (Laos, et al., 2016).

\section{Tabel 1 Karakteristik Karbon Aktif Kayu Merbau Setelah Diaktivasi}

\begin{tabular}{|c|c|c|c|c|}
\hline \multirow[b]{2}{*}{ Sampel } & \multicolumn{4}{|c|}{ Hasil Pengujian } \\
\hline & $\begin{array}{c}\text { Kadar Air } \\
(\%)\end{array}$ & $\begin{array}{c}\text { Kadar Abu } \\
(\%)\end{array}$ & $\begin{array}{c}\text { Daya Serap } \mathbf{I}_{2} \\
(\mathrm{mg} / \mathrm{g})\end{array}$ & $\begin{array}{c}\text { Daya Serap } \\
\mathbf{I}_{2}(\%) \\
\end{array}$ \\
\hline $\begin{array}{l}\text { I. Karbon aktif yang diaktivasi } \\
\text { secara fisik dgn pemanasan } \\
700^{\circ} \mathrm{C}\end{array}$ & 8.93 & 8.93 & 122 & 6.1 \\
\hline $\begin{array}{ll}\text { II. } & \text { Karbon Aktif yang } \\
\text { diaktivasi dengan }[\mathrm{HCl} 1 \mathrm{M}]\end{array}$ & 8.80 & 0.65 & 477 & 23.85 \\
\hline $\begin{array}{l}\text { III. Karbon aktif yang diaktivasi } \\
\text { dengan }[\mathrm{HCl} 2 \mathrm{M}]\end{array}$ & 23.59 & 0.78 & 680 & 34 \\
\hline $\begin{array}{l}\text { IV. Karbon aktif yang diaktivasi } \\
\text { dengan }[\mathrm{HCl} 3 \mathrm{M}]\end{array}$ & 20.86 & 0.99 & 781 & 39.05 \\
\hline
\end{tabular}

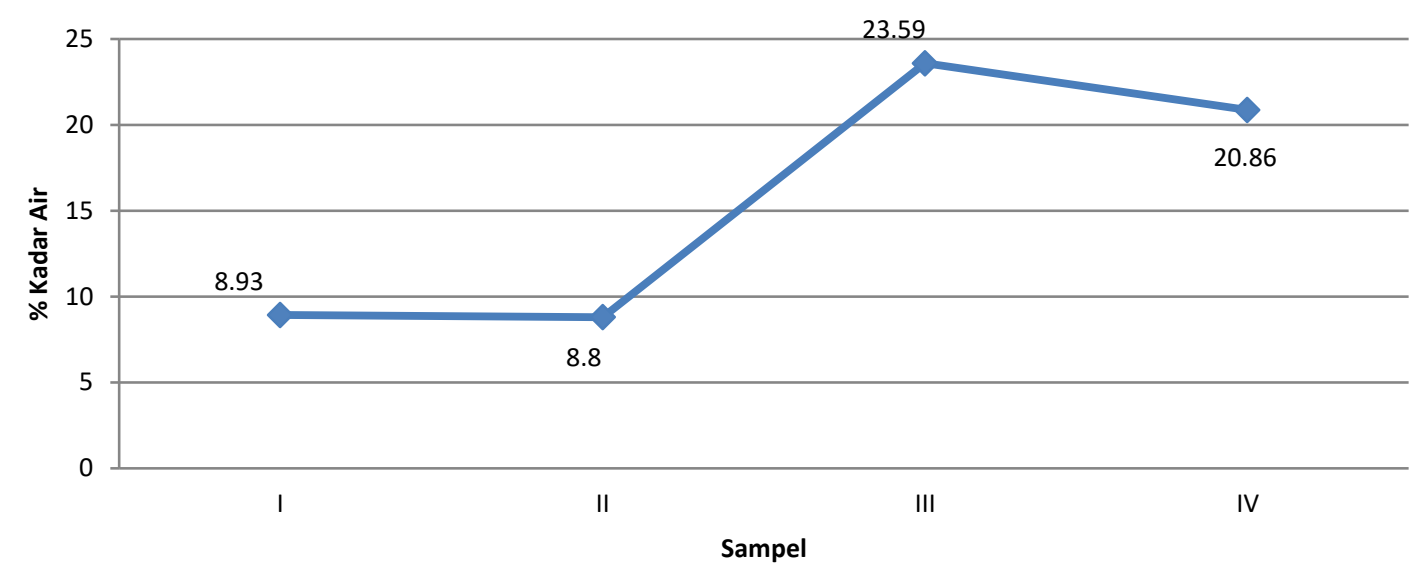

Gambar 1 Kurva Hubungan Kadar Air Sampel Dengan Metode Aktivasi

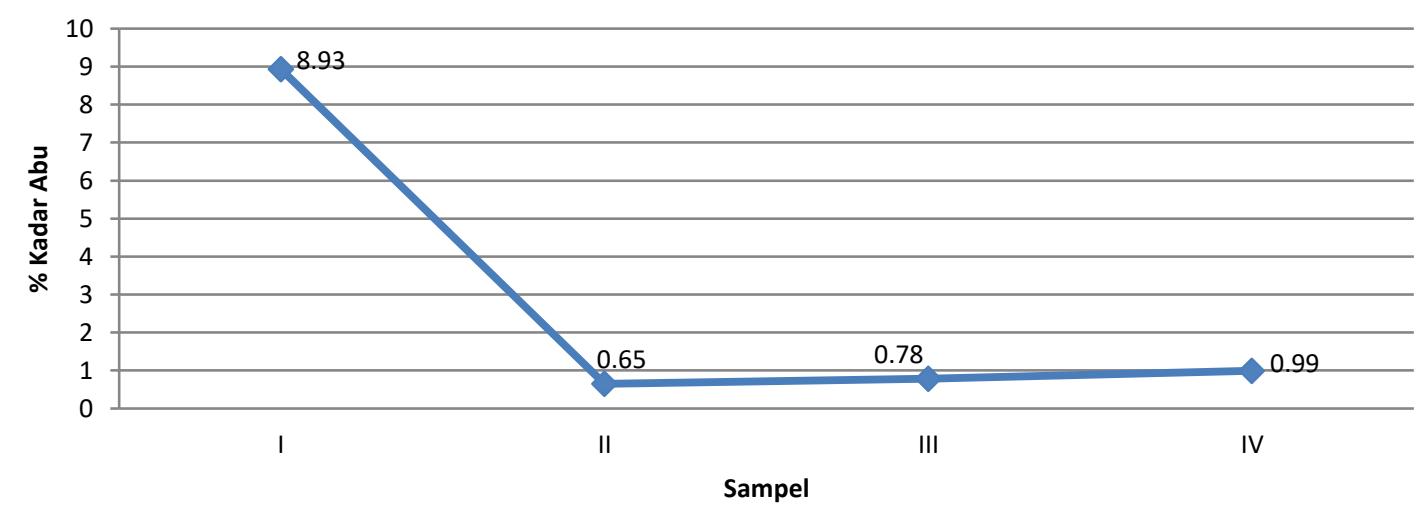

Gambar 2 Kurva hubungan kadar abu sampel dengan metode aktivasi 


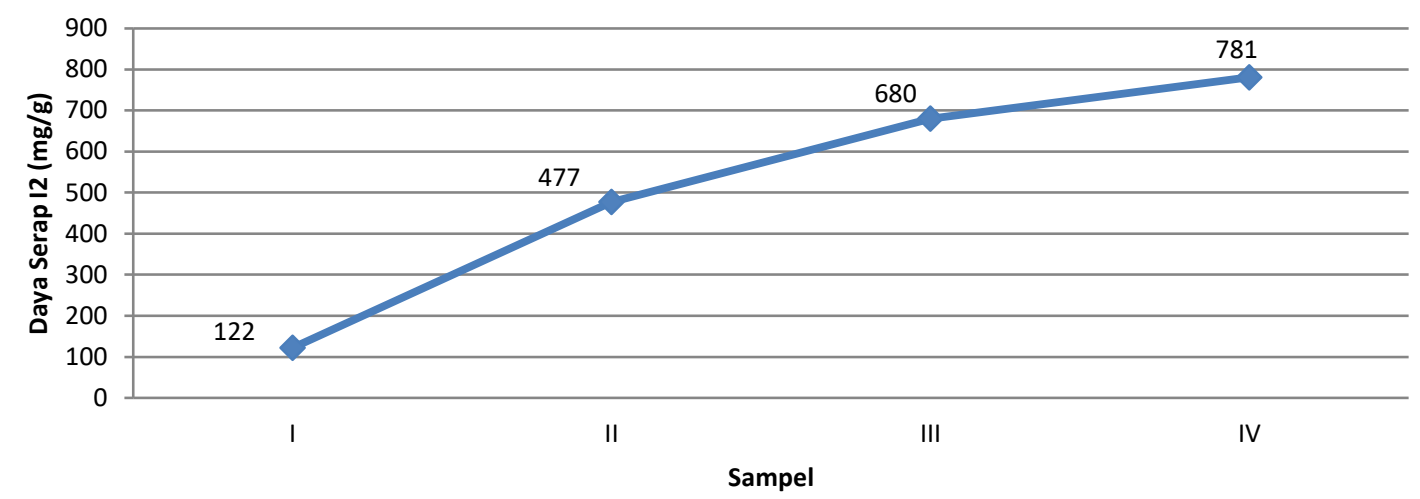

Gambar 3 Kurva Daya serap I 2 Tiap Sampel

Perbedaan metode aktivasi arang kayu merbau dalam menentukan kadar abu menunjukkan adanya pengaruh yang signifikan (Gambar 2). Arang kayu merbau yang diaktivasi secara fisik (sampel I) memiliki kadar abu sebesar $8.93 \%$. Sedangkan arang kayu merbau yang diaktivasi secara kimia dengan penambahan $\mathrm{HCl} 1 \mathrm{M}$ (sampel II) memiliki kadar abu sebesar $0.65 \%$.

Penggunaan $\mathrm{HCl}$ untuk mengaktivasi arang kayu merbau sangat berpengaruh terhadap penurunan kadar abu karbon aktif kayu merbau karena aktivator $\mathrm{HCl}$ merupakan salah satu asam kuat yang mampu mengikat atau melarutkan zat-zat pengotor pada permukaan karbon aktif kayu merbau kemudian menguap atau hilang selama proses pengabuan. Zat-zat pengotor tersebut dapat berupa tar, oksida logam dan mineral-mineral lainnya yang terbentuk selama proses karbonisasi. Oleh karena itu, permukaan karbon aktif kayu merbau menjadi terbuka dan luas permukaan karbon aktif akan semakin besar sehingga kemampuan karbon aktif ini semakin besar untuk menyerap substrat baik berupa gas ataupun cairan.

Semakin tinggi konsentrasi $\mathrm{HCl}$ yang digunakan untuk mengaktivasi sampel maka kadar abu yang dihasilkan semakin tinggi (Gambar 2).
Peningkatan kadar abu dapat terjadi akibat terbentuknya garam-garam mineral pada saat proses pengabuan yang bila dilanjutkan akan membentuk partikel-partikel halus dari mineral garam tersebut. Hal ini disebabkan karena adanya kandungan bahan mineral yang terdapat didalam bahan awal biomassa pembuat karbon (Laos, et al., 2016).

Pengujian karakteristik karbon aktif kayu merbau selanjutnya adalah daya serap $I_{2}$ (iodin). Penentuan daya serap iodin bertujuan untuk menentukan kapasitas adsorpsi karbon aktif (Jankowska, et al., 1991; Sahara, et al., 2017). Menurut Budiono, et al., (2009) dalam Prastiwi (2014), daya serap iodin ditunjukkan dengan besarnya bilangan iod, yaitu angka yang menunjukkan seberapa besar adsorben dapat mengadsorpsi iod. Daya serap iodin berkorelasi dengan luas permukaan karbon aktif karena semakin besar daya serap iod maka semakin besar kemampuan dalam mengadsorpsi larutan atau substrat tersebut.

Daya serap $\mathrm{I}_{2}$ yang ditujukan pada Tabel 1 dan Gambar 3 terlihat bahwa semakin tinggi konsentrasi $\mathrm{HCl}$ yang digunakan untuk merendam karbon aktif, maka daya serap $\mathrm{I}_{2}$ semakin tinggi. Hal ini menunjukkan bahwa konsentrasi $\mathrm{HCl} 3 \mathrm{M}$ efektif untuk 
menghilangkan oksida-oksida logam dan kotoran lain yang menempel pada permukaan karbon, sehingga pori-pori pada permukaan karbon lebih terbuka untuk menyerap adsorbat.

\section{Karakteristik Limbah Cair Industri Tahu Tempe Rizky Dan Sukamaju}

\section{Variasi Konsentrasi Aktivator $\mathrm{HCl}$}

Besarnya daya serap karbon aktif kayu merbau atau penurunan kadar $\mathrm{BOD}_{5}$ dan COD pada limbah cair industry tahu tempe Rizky dan Sukamaju dapat dilihat dalam Tabel 2.

Tabel 2 menunjukkan bahwa daya serap karbon aktif (\%) untuk nilai $\mathrm{BOD}_{5}$ dan COD dalam limbah cair industri tahu tempe Sukamaju lebih tinggi dibandingkan dengan industri tahu tempe Rizky. Dalam sampel II, yaitu karbon aktif diaktivasi fisik atau diaktivasi tanpa karbon aktif menghasilkan $\mathrm{BOD}_{5}$ yang diserap dari limbah cair industri tahu tempe Sukamaju adalah sebanyak $70.44 \%$ sedangkan $\mathrm{BOD}_{5}$ yang diserap dari limbah cair industri tahu tempe Rizky sebanyak $43.21 \%$. Selain itu, COD yang diserap dari limbah cair industry tahu tempe Sukamaju juga lebih tinggi dibandingkan dengan COD yang diserap dari limbah cair industri tahu tempe Rizky. COD yang diserap dari limbah cair industri tahu tempe Sukamaju sebesar $82.42 \%$ dan COD yang diserap dari limbah cair industry tahu tempe Rizky adalah sebesar 25.94\%. Hal ini juga terjadi pada sampel III sampai dengan sampel V. Adanya perbedaan daya serap karbon aktif dalam limbah cair industri tahu tempe Sukamaju dan Rizky disebabkan oleh adanya perbedaan $\mathrm{pH}$ dari limbah cair kedua indutri tersebut. Limbah cair indutri tahu tempe Sukamaju memiliki $\mathrm{pH}$ adalah 7.3, sedangkan $\mathrm{pH}$ limbah cair industri tahu tempe Rizky adalah 4.8 .

Hubungan daya serap karbon aktif dengan nilai $\mathrm{BOD}_{5}$ dan $\mathrm{COD}$ dalam limbah cair industry tahu tempe Sukamaju dan Rizky dapat dilihat dalam Gambar 4.

\section{Tabel 2 Daya Serap Karbon Aktif (\%) Kayu Merbau Terhadap Parameter BODs Dan COD Limbah Cair Industri Tahu Tempe Dengan Variasi Konsentrasi HCl}

\begin{tabular}{|c|c|c|c|c|}
\hline \multirow{3}{*}{ Sampel } & \multicolumn{2}{|c|}{ Rizky } & \multicolumn{2}{|c|}{ Sukamaju (SKMJ) } \\
\hline & \multicolumn{4}{|c|}{ Daya Serap $(\%)$} \\
\hline & COD & BOD5 & COD & BOD5 \\
\hline $\begin{array}{l}\text { II. Karbon aktif yang diaktivasi fisik } \\
\text { dengan pemanasan } 700^{\circ} \mathrm{C}(\text { tanpaHCl })\end{array}$ & 25.94 & 43.21 & 82.42 & 70.44 \\
\hline $\begin{array}{l}\text { III. Karbon aktif yang diaktivasi dengan } \\
{[\mathrm{HCl} 1 \mathrm{M}]}\end{array}$ & 27.25 & 40.99 & 85.77 & 74.31 \\
\hline $\begin{array}{l}\text { IV. Karbon aktif yang diaktivasi dengan } \\
{[\mathrm{HCl} 2 \mathrm{M}]}\end{array}$ & 47.08 & 50.86 & 86.94 & 73.20 \\
\hline $\begin{array}{l}\text { V. Karbon aktif yang diaktivasi dengan } \\
{[\mathrm{HCl} 3 \mathrm{M}]}\end{array}$ & 53.19 & 51.36 & 87.76 & 75.69 \\
\hline
\end{tabular}




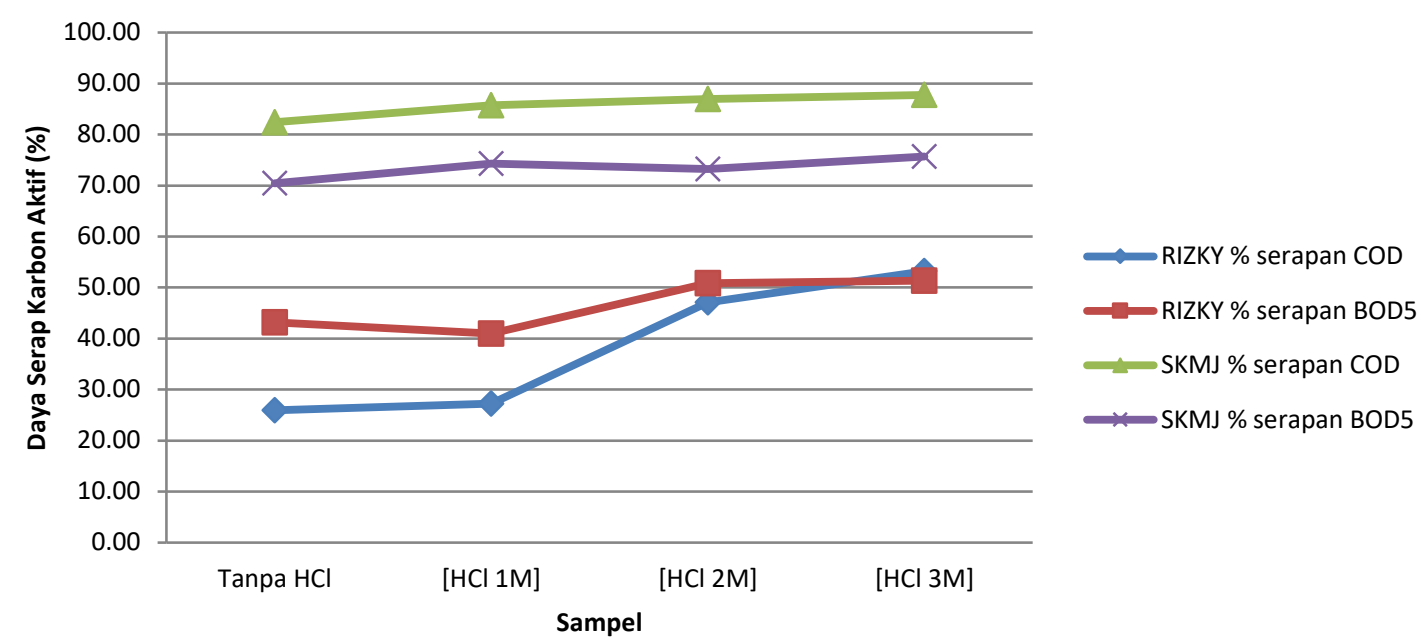

Gambar 4 Daya serap Karbon Aktif Kayu Merbau (\%) dengan variasi konsentrasi $\mathrm{HCl}$ terhadap Parameter $\mathrm{BOD}_{5}$ dan COD.

Tabel 3. Daya Serap Karbon Aktif (\%) Kayu Merbau terhadap parameter BOD 5 dan COD Dengan Variasi Waktu Kontak

\begin{tabular}{ccccc}
\hline \multirow{2}{*}{ Waktu Kontak } & \multicolumn{2}{c}{ Rizky } & \multicolumn{2}{c}{ Sukamaju (SKMJ) } \\
& BOD5 & COD & BOD5 & COD \\
\hline 30 menit & 89.18 & 88.30 & 80.44 & 77.12 \\
60 menit & 37.36 & 34.91 & 42.22 & 36.41 \\
90 menit & 36.81 & 35.41 & 20.00 & 22.69 \\
120 menit & 40.11 & 39.88 & 39.78 & 55.38 \\
\hline
\end{tabular}

Peningkatan konsentrasi $\mathrm{HCl}$ hingga 3M untuk mengaktivasi karbon aktif kayu merbau dapat meningkatkan atau menurunkan kadar $\mathrm{BOD}_{5}$ dan COD dalam air limbah. Daya serap karbon aktif tertinggi atau penurunan kadar $\mathrm{BOD}_{5}$ tertinggi pada limbah cair industri tahu tempe Sukamaju adalah sebesar $87.79 \%$ dengan penggunaan karbon aktif kayu merbau yang diaktivasi secara kimia dengan $\mathrm{HCl} 3 \mathrm{M}$. Daya serap karbon aktif atau penurunan kadar COD tertinggi dalam limbah cair industri tahu tempe Sukamaju adalah sebesar $75.69 \%$ dengan penggunaan karbon aktif kayu merbau yang diaktivasi secara kimia dengan $\mathrm{HCl} 3 \mathrm{M}$. Sedangkan daya serap karbon aktif tertinggi atau penurunan $\mathrm{BOD}_{5}$ tertinggi pada limbah cair industri tahu tempe Rizky adalah sebesar $51.36 \%$ dengan penggunaan karbon aktif kayu merbau yang diaktivasi secara kimia dengan $\mathrm{HCl}$ 3M. Daya serap karbon aktif tertinggi atau penurunan kadar COD tertinggi dalam limbah cair industri tahu tempe Rizky adalah sebesar 53.18\% dengan penggunaan karbon aktif kayu merbau yang diaktivasi secara kimia dengan $\mathrm{HCl} 3 \mathrm{M}$.

\section{Variasi Waktu Kontak Karbon Aktif Dengan Limbah Cair}

Karakteristik limbah cair industry tahu tempe Rizky dan Sukamaju setelah penggunaan karbon aktif kayu merbau atau setelah adsorpsi diketahui dari besarnya daya serap karbon aktif kayu merbau atau penurunan kadar $\mathrm{BOD}_{5}$ dan $\mathrm{COD}$ dalam limbah cair kedua industry tahu tempe 
tersebut. Hal ini dapat dilihat dalam Tabel 3.

Semakin lama waktu kontak karbon aktif dengan limbah cair industry tahu tempe Rizky dan Sukamaju, maka daya serap karbon aktif tersebut akan semakin menurun (Tabel 3). Namun daya serap karbon aktif meningkat kembali dengan penambahan waktu kontak. Hal ini menunjukkan bahwa karbon aktif memiliki titik jenuh adsorpsi dan bersifat sementara. Waktu kontak 90 menit merupakan waktu kontak dengan daya serap karbon aktif terendah atau saat 90 menit karbon aktif mengalami titik jenuh adsorpsi. Setelah jenuh, karbon aktif menunjukkan peningkatan daya serapnya saat waktu kontak 120 menit.

\section{Variasi Volume Limbah Cair Industri Tahu tempe Rizky Dan Sukamaju}

Penurunan kadar $\mathrm{BOD}_{5}$ dan COD dalam limbah cair industry tahu tempe setelah proses adsorpsi menunjukkan kemampuan karbon aktif kayu merbau dalam mengadsorpsi zat atau bahan organic. Untuk mengetahui besarnya daya serap karbon aktif ini dapat dilihat pada Tabel 4.

Rendahnya daya serap karbon aktif kayu merbau dalam limbah cair industry tahu tempe Rizky disebabkan oleh tingginya suhu limbah cair tersebut, yaitu sebesar $34^{\circ} \mathrm{C}$. Hal ini sesuai dengan Sulistyani et al. 2013 bahwa salah satu factor yang dapat mempengaruhi adsorpsi karbon aktif adalah suhu. Dimana semakin tinggi suhu maka karbon aktif semakin sulit menyerap zat atau bahan dalam limbah cair. Sebaliknya semakin rendah suhu maka karbon aktif semakin mudah menyerap zat atau bahan dalam limbah cair. Sedangkan suhu limbah cair industry tahu tempe Sukamaju adalah $29^{\circ} \mathrm{C}$ sehingga adsorpsi karbon aktif pada limbah cair tersebut menjadi maksimal.

Pengaruh Metode Aktivasi Karbon Aktif Terhadap Penurunan Kadar BOD5 dan COD Limbah Cair Industri Tahu Tempe Rizky dan Sukamaju

Kadar BOD5 dan COD limbah cair industry tahu tempe Sukamaju sebelum proses adsorpsi adalah masing-masing sebesar $362 \mathrm{mg} / \mathrm{l}$ dan $1462 \mathrm{mg} / \mathrm{l}$. setelah proses adsorpsi dengan metode aktivasi fisik, kadar $\mathrm{BOD}_{5}$ dan CODnya menjadi sebesar $107 \mathrm{mg} / \mathrm{l}$ dan $257 \mathrm{mg} / \mathrm{l}$. Hasil ini menunjukkan bahwa terjadi penurunan kadar $\mathrm{BOD}_{5}$ dan $\mathrm{COD}$ pada limbah cair industry tahu tempe Sukamaju sebesar $70.44 \%$ dan $82.42 \%$. Sedangkan kadar $\mathrm{BOD}_{5}$ dan COD limbah cair industry tahu tempe Sukamaju setelah proses adsorpsi dengan metode aktivasi secara kimia dengan $\mathrm{HCl} 1 \mathrm{M}$ adalah sebesar $93 \mathrm{mg} / \mathrm{l}$ dan $208 \mathrm{mg} / \mathrm{l}$. Hasil ini menunjukkan bahwa terjadi penurunan kadar $\mathrm{BOD}_{5}$ dan COD pada limbah cair industry tahu tempe Sukamaju sebesar $74.31 \%$ dan $85.77 \%$. Semakin tinggi konsentrasi $\mathrm{HCl}$ yang digunakan maka penurunan kadar $\mathrm{BOD}_{5}$ dan $\mathrm{COD}$ pada limbah industry tahu tempe Sukamaju Semakin besar.

Hasil penelitian ini menunjukkan bahwa penurunan kadar $\mathrm{BOD}_{5}$ dan COD pada limbah cair industry tahu tempe Rizky dan Sukamaju lebih besar dengan menggunakan metode aktivasi secara kimia dengan $\mathrm{HCl}$ dibandingkan dengan metode aktivasi fisik. Hal ini disebabkan oleh $\mathrm{HCl}$ merupakan salah satu asam kuat yang mampu mengikat atau melarutkan zatzat pengotor pada permukaan karbon aktif kayu merbau kemudian menguap 
atau hilang selama proses pengabuan. Zat-zat pengotor tersebut dapat berupa tar, oksida logam dan mineral-mineral lainnya yang terbentuk selama proses karbonisasi. Oleh karena itu, permukaan karbon aktif kayu merbau menjadi terbuka dan luas permukaan karbon aktif akan semakin besar sehingga kemampuan karbon aktif ini semakin besar untuk menyerap substrat baik berupa gas ataupun cairan.

Tabel 4 Pengaruh Volume Limbah Cair Terhadap Daya Serap (\%) Karbon Aktif Kayu Merbau

\begin{tabular}{ccccc}
\hline \multirow{2}{*}{ Volume Limbah Cair } & \multicolumn{2}{c}{ Rizky } & \multicolumn{2}{c}{ Sukamaju (SKMJ) } \\
& BOD5 & COD & BOD5 & COD \\
\hline $100 \mathrm{ml}$ & 0.80 & 14.30 & 82.4 & 82.10 \\
$150 \mathrm{ml}$ & 28.60 & 10.90 & 53.2 & 30.80 \\
$200 \mathrm{ml}$ & 16.40 & 2.50 & 47.2 & 31.10 \\
$250 \mathrm{ml}$ & 60.60 & 25.50 & 45.2 & 34.80 \\
$300 \mathrm{ml}$ & 29.2 & 11.80 & 39 & 30.90 \\
\hline
\end{tabular}

Tabel 5 Pengaruh Konsentrasi HCl Terhadap Kapasitas Adsorpsi Karbon Aktif Kayu Merbau (mg/g)

\begin{tabular}{|c|c|c|c|c|}
\hline \multirow[b]{2}{*}{ Sampel } & \multicolumn{2}{|c|}{ SKMJ } & \multicolumn{2}{|c|}{ Rizky } \\
\hline & $\begin{array}{l}\text { Qe } \\
\text { BOD5 }\end{array}$ & $\begin{array}{c}\text { Qe } \\
\text { COD }\end{array}$ & $\begin{array}{l}\text { Qe } \\
\text { BOD5 }\end{array}$ & $\begin{array}{l}\text { Qe } \\
\text { COD }\end{array}$ \\
\hline $\begin{array}{l}\text { II.Karbon aktif yang diaktivasi fisik dengan } \\
\text { pemanasan } 700^{\circ} \mathrm{C}(\text { tanpa } \mathrm{HCl})\end{array}$ & 51,000 & 241,000 & 35,000 & 95,040 \\
\hline $\begin{array}{l}\text { III. Karbon aktif yang diaktivasi dengan } \\
{[\mathrm{HCl} 1 \mathrm{M}]}\end{array}$ & 53,800 & 250,800 & 33,200 & 99,840 \\
\hline $\begin{array}{l}\text { IV. Karbon aktif yang diaktivasi dengan }[\mathrm{HCl} \\
2 \mathrm{M}]\end{array}$ & 53,000 & 254,200 & 41,200 & 172,440 \\
\hline $\begin{array}{l}\text { V. Karbon aktif yang diaktivasi dengan }[\mathrm{HCl} \\
3 \mathrm{M}]\end{array}$ & 54,800 & 256,600 & 41,600 & 194,840 \\
\hline
\end{tabular}

Penggunaan metode aktivasi secara kimia dengan $\mathrm{HCl} 1 \mathrm{M}, 2 \mathrm{M}$ dan $3 \mathrm{M}$ juga memberikan pengaruh terhadap penurunan kadar $\mathrm{BOD}_{5}$ dan COD pada limbah cair industry tahu tempe Rizky dan Sukamaju. Semakin tinggi konsentrasi $\mathrm{HCl}$ yang digunakan maka penurunan kadar $\mathrm{BOD}_{5}$ dan $\mathrm{COD}$ pada limbah cair kedua industry tahu tempe tersebut akan semakin besar dan penurunan tertinggi adalah dengan $\mathrm{HCl}$ 3M.

Tingginya penurunan kadar $\mathrm{BOD}_{5}$ dan COD atau daya serap karbon aktif kayu merbau yang diaktivasi $\mathrm{HCl} 3 \mathrm{M}$ menunjukkan bahwa permukaan karbon aktif memiliki luas permukaan yang besar sehingga maksimal untuk mengadsorpsi $\mathrm{BOD}_{5}$ dan COD dalam limbah cair industry tahu tempe. Luasnya permukaan karbon aktif ini dapat diketahui dari besarnya kapasitas adsorpsi yang dimiliki karbon aktif ini dalam mengadsorpsi zat atau susbtrat dalam limbah cair.

Kapasitas adsorpsi karbon aktif menunjukkan besarnya luasnya permukaan karbon aktif untuk menyerap zat atau substrat dan dengan penggunaan 
$\mathrm{HCl}$ untuk mengaktifkan arang kayu merbau maka kapasitas adsorpsinya makin besar seiring dengan kenaikan konsentrasi $\mathrm{HCl}$.

\section{Pengaruh Waktu Kontak terhadap Kapasitas Adsorpsi Karbon Aktif}

Pengaruh waktu kontak terhadap kapasitas adsorpsi kayu merbau ditunjukkan dalam Gambar 5.

Secara umum semakin lama waktu kontak yang diberikan pada sampel maka kapasitas adsorpsi karbon aktif semakin menurun, namun kapasitas adsorpsi kembali naik pada waktu kontak tertentu. Kapasitas adsorpsi dengan waktu kontak 30 menit adalah kapasitas adsorpsi tertinggi kemudian makin menurun pada waktu kontak 60 dan 90 menit, namun pada waktu kontak 120 menit kapasitas adsorpsi kembali naik (Gambar 5).

Proses adsorpsi dengan waktu kontak 90 menit menunjukkan bahwa karbon aktif telah jenuh sehingga adsorpsinya sangat rendah. Namun, ikatan yang terjadi antara permukaan karbon aktif dan substrat lemah maka ikatan ini menjadi terlepas kembali sehingga permukaan karbon aktif yang tadinya terikat substrat menjadi kosong. Semakin lama waktu kontak yang diberikan pada karbon aktif dan limbah cair maka kesempatan substrat untuk kembali terikat semakin besar sehingga kapasitas adsorpsi karbon aktif kembali meningkat. Ini sesuai dengan pernyataan Suyata (2009) yang menyatakan bahwa peristiwa adsorpsi pada arang aktif terjadi karena adanya Gaya Van Der Waals, yaitu gaya tarik-menarik intermolekular antara molekul padatan dengan solute yang diadsorpsi lebih besar daripada gaya tarik-menarik sesama solute itu sendiri didalam larutan, maka solute akan terkonsentrasi pada permukaan padatan. Hal tersebut didukung oleh pernyataan Notodarmojo (2005) bahwa proses adsorpsi pada zat organik merupakan adsorpsi fisik dan didominasi oleh Gaya Van Der Waals yang mempunyai ikatan yang lemah sehingga bersifat reversible atau dapat terlepas kembali.

\section{Penentuan Kapasitas Adsorpsi Optimum Karbon Aktif Kayu Merbau}

Secara umum terlihat bahwa semakin besar volume limbah yang diserap/ di adsorpsi kadar $\mathrm{BOD}_{5}$ dan COD limbah cair industry tahu tempe Rizky dan Sukamaju, maka kapasitas adsorpsi karbon aktif semakin besar.

Hubungan volume limbah cair industry tahu tempe Rizky dengan besarnya kapasitas adsorpsi karbon aktif dalam menyerap $\mathrm{BOD}_{5}$ dan COD disajikan dalam Gambar 6.

Kapasitas adsorpsi maksimum dari karbon aktif dalam menyerap COD maksimal pada penggunaan limbah cair industry tahu tempe Rizky adalah pada volume $250 \mathrm{ml}$, sedangkan kapasitas adsorpsi maksimum dari karbon aktif dalam menyerap $\mathrm{BOD}_{5}$ limbah cair industry tersebut adalah pada volume $300 \mathrm{ml}$.

Tingginya kapasitas adsorpsi karbon aktif dalam menyerap COD ini menyebabkan daya serap karbon aktif (\%) menjadi maksimal, yaitu $25.50 \%$. Namun, pada volume limbah $300 \mathrm{ml}$ yang kapasitas adsorpsinya maksimum menyerap $\mathrm{BOD}_{5}$ limbah cair industry tahu tempe Rizky menghasilkan daya serap yang minimum, yaitu $29.2 \%$. Hal ini disebabkan oleh pada volume limbah $250 \mathrm{ml}$ telah terjadi adsorpsi BOD5 maksimal dari karbon aktif kayu merbau sebesar $60.60 \%$ sehingga saat penambahan volume limbah menjadi $300 \mathrm{ml}$, daya serap karbon aktif menurun. 
Hubungan volume limbah cair industry tahu tempe Sukamaju dengan besarnya kapasitas adsorpsi karbon aktif dalam menyerap $\mathrm{BOD}_{5}$ dan $\mathrm{COD}$ disajikan dalam Gambar 7.

Peningkatan volume limbah cair industry tahu tempe Sukamaju dapat meningkatkan kapasitas adsorpsi karbon aktif kayu merbau tetapi daya serap karbon aktifnya semakin menurun. Daya serap karbon aktif sudah tidak dapat maksimum seperti daya serap karbon aktif pada volume limbah 100 $\mathrm{ml}$.

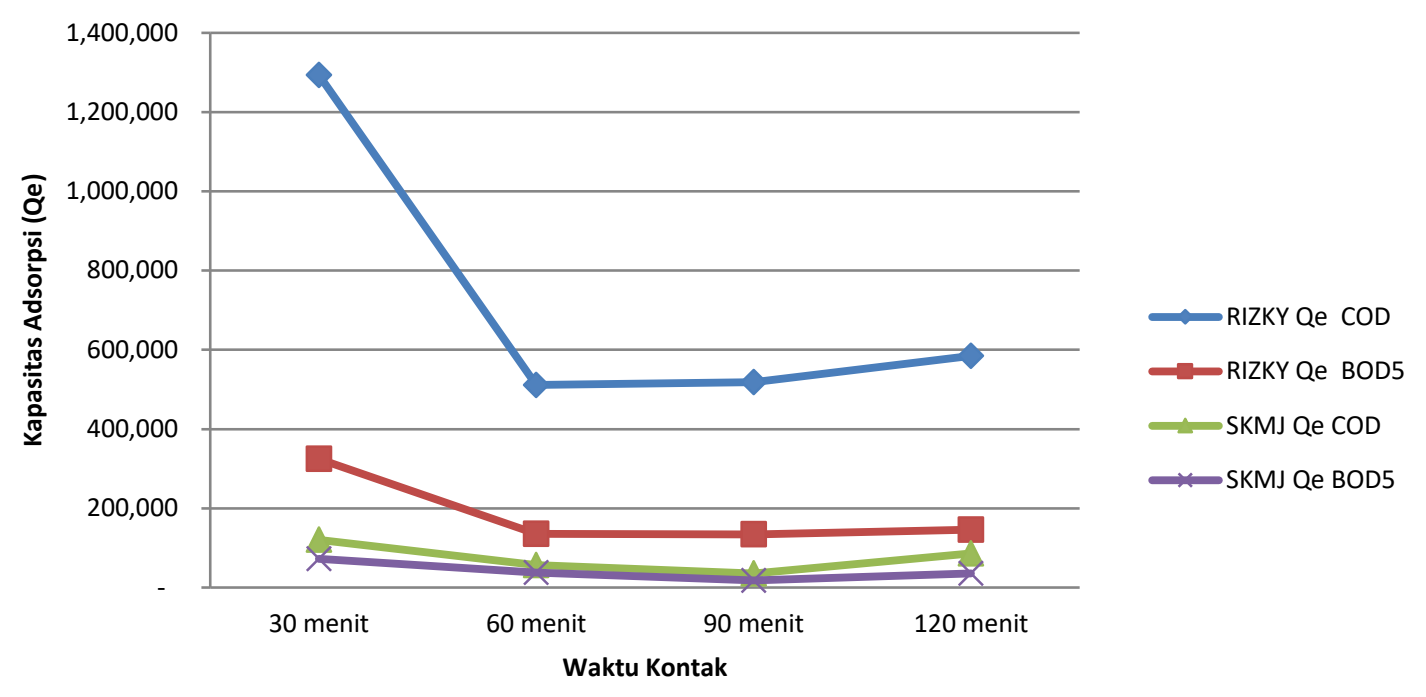

Gambar 5 Kurva pengaruh waktu kontak terhadap kapasitas adsorpsi

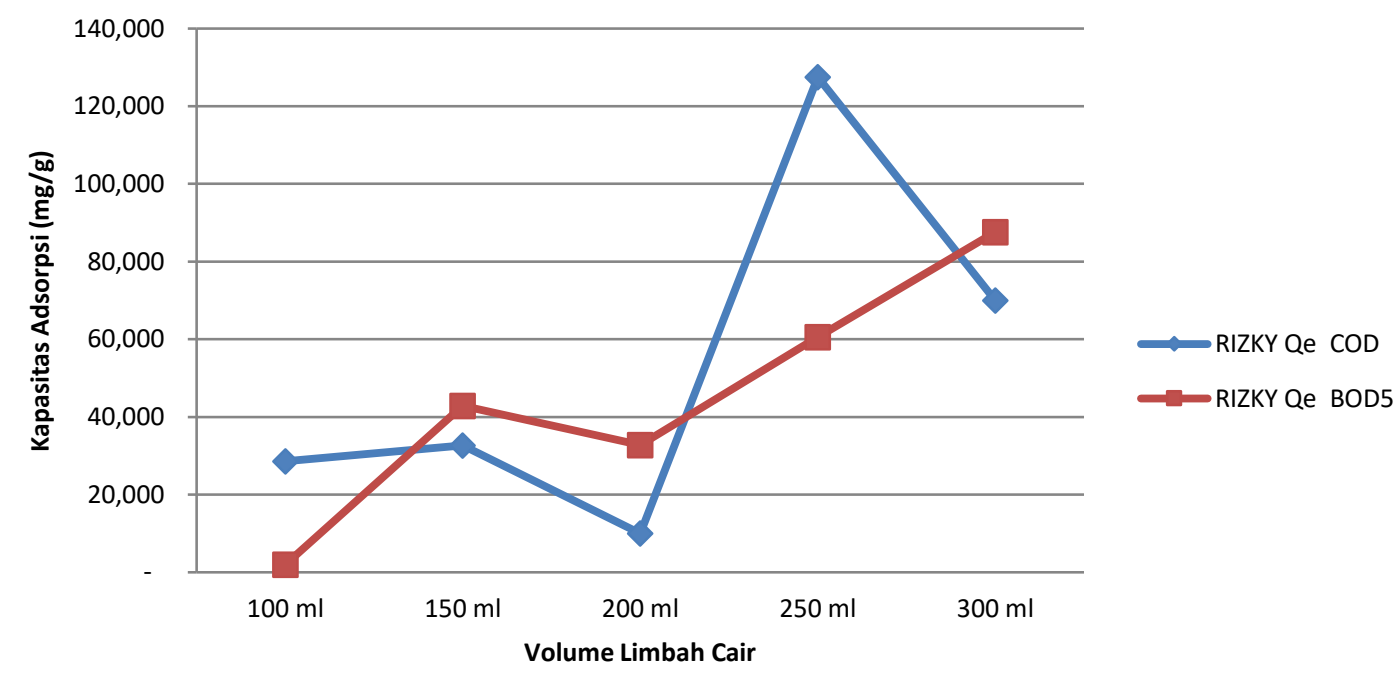

Gambar 6 Kurva hubungan volume limbah cair industry tahu tempe Rizky dengan kapasitas adsorpsi karbon aktif kayu merbau 


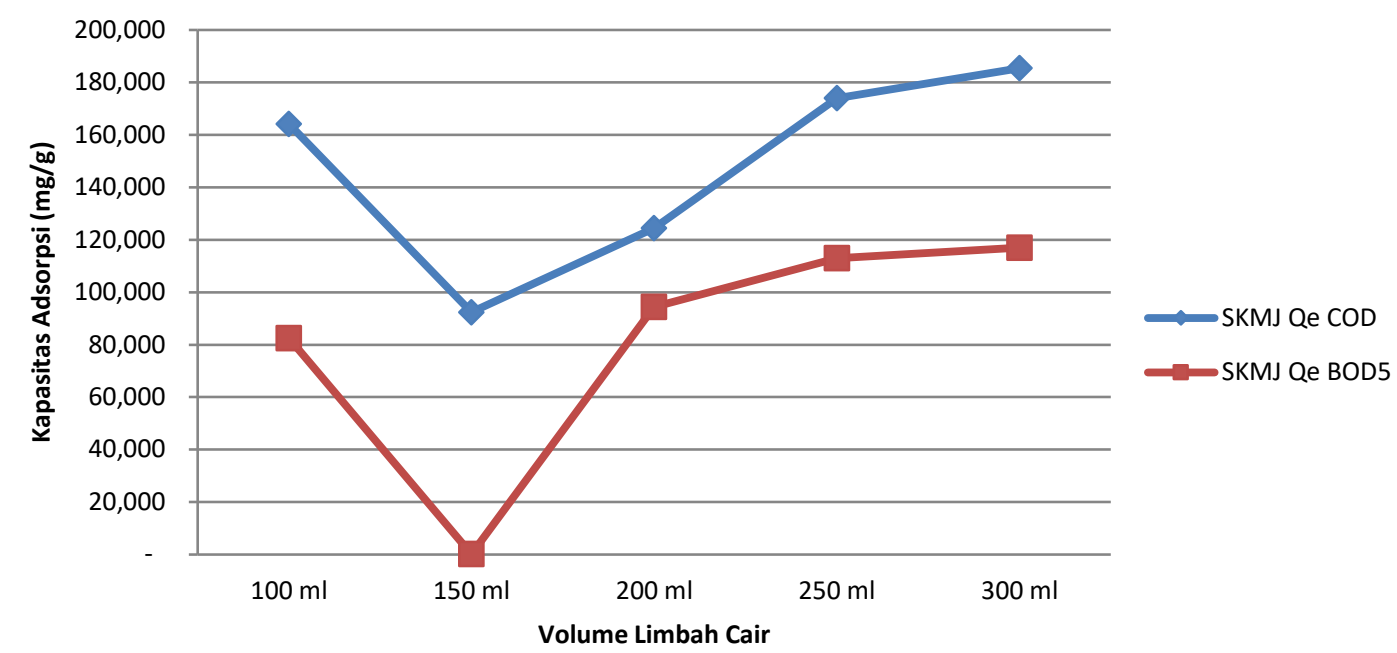

Gambar 7 Kurva hubungan volume limbah cair industry tahu tempe Sukamaju dengan kapasitas adsorpsi karbon aktif kayu merbau.

Hasil diatas dapat disimpulkan bahwa kapasitas adsorpsi optimum karbon aktif kayu mebau untuk menyerap $\mathrm{BOD}_{5}$ dan $\mathrm{COD}$ limbah cair industry tahu tempe Rizky adalah pada volume limbah $250 \mathrm{ml}$, yaitu masingmasing sebesar 60,600 $\mathrm{mg} / \mathrm{g}$ dan $127,500 \mathrm{mg} / \mathrm{g}$. Kapasitas adsorpsi optimum karbon aktif kayu merbau untuk menyerap atau menurunkan kadar $\mathrm{BOD}_{5}$ dan COD limbah cair industry tahu tempe Sukamaju adalah pada volume limbah $100 \mathrm{ml}$, yaitu masingmasing sebesar $82,400 \mathrm{mg} / \mathrm{g}$ dan $164,200 \mathrm{mg} / \mathrm{g}$.

\section{KESIMPULAN}

1. Konsentrasi optimum $\mathrm{HCl}$ yang digunakan untuk mengaktivasi arang kayu merbau dalam menurunkan kadar $\mathrm{BOD}_{5}$ dan $\mathrm{COD}$ limbah rganic industri tahu tempe adalah $\mathrm{HCl} 3 \mathrm{M}$.

2. Waktu kontak optimum karbon aktif kayu merbau dalam menurunkan kadar $\mathrm{BOD}_{5}$ dan $\mathrm{COD}$ limbah organic industri tahu tempe adalah 30 menit.
3. Kapasitas adsorpsi optimum karbon aktif kayu merbau dalam menurunkan kadar $\mathrm{BOD}_{5}$ dan $\mathrm{COD}$ limbah organic tahu tempe adalah :

a. Kapasitas adsorpsi optimum karbon aktif kayu merbau dalam menurunkan kadar $\mathrm{BOD}_{5}$ dan COD limbah organic industri tahu tempe Rizky masingmasing adalah $60,600 \mathrm{mg} / \mathrm{g}$ dan $127,500 \mathrm{mg} / \mathrm{g}$ pada volume limbah cair $250 \mathrm{ml}$.

b. Kapasitas adsorpsi optimum karbon aktif kayu merbau dalam menurunkan kadar $\mathrm{BOD}_{5}$ dan COD limbah organic industri tahu tempe Sukamaju masingmasing adalah $82,400 \mathrm{mg} / \mathrm{g}$ dan $164,200 \mathrm{mg} / \mathrm{g}$ pada volume limbah cair $100 \mathrm{ml}$.

\section{SARAN}

1. Pemilik industri tahu tempe diharapkan dapat mempertimbangkan cara pengolahan limbah cairnya menggunakan metode karbon aktif khususnya karbon aktif kayu merbau. 
2. Pemerintah Kabaupaten Manokwari dalam hal ini Dinas Lingkungan Hidup dapat mempertimbangkan alternatif cara pengolahan limbah cair industri tahu tempe dengan metode karbon aktif ini.

3. Penelitian lanjutan dengan memvariasikan berat karbon aktif yang digunakan untuk menurunkan kadar $\mathrm{BOD}_{5}$ dan $\mathrm{COD}$ dalam limbah organic industri tahu tempe dan efisiensi karbon aktif dalam menurunkan kadar $\mathrm{BOD}_{5}$ dan COD dalam limbah organic industri tahu tempe.

\section{DAFTAR PUSTAKA}

Endah N. 2005. Pengaruh konsentrasi activator $\mathrm{Na}_{2} \mathrm{SO}_{4}$ terhadap daya adsorpsi karbon aktif tempurung kelapa pada ion $\mathrm{Cd}^{2+}$ : kasus Makassar [skripsi]. Makassar: Fakultas Matematika Dan Ilmu Pengetahuan Alam, Universitas Negeri Makassar.

Laos E. Landiana, Masturi, Yulianti Ian. 2016. Pengaruh Suhu Aktivasi Terhadap Daya Serap Karbon Aktif Kulit Kemiri. SNF2016;5.

Prastiwi A. Dini. 2014. Penggunaan $\mathrm{ZnCl}_{2}$ sebagai activator karbon aktif dari limbah padat agar dan aplikasinya sebagai adsorben pada limbah cair industry tahu. [Skripsi]. Bogor: Fakultas Perikanan Dan Ilmu Kelautan, Institut Pertanian Bogor.

Sahara E, Sulihingtyas WD, Mahardika AS. I Putu. 2017. Pembuatan Dan Karakterisasi Arang Aktif Dari Batang Tanaman Gumitir (Tagetes erecta) Yang Diaktivasi Dengan $\mathrm{H}_{3} \mathrm{PO}_{4}$. Jurnal Kimia, ISSN 19079850 11(1): 1-9.
Sulistyani E, Budi E dan Bakri F. 2013. Pengaruh temperatur terhadap adsorpsi karbon aktif berbentuk pellet untuk aplikasi filter air: Di dalam: Seminar Nasional Fisika; Universitas Negeri Jakarta, 1 Juni 2013. 